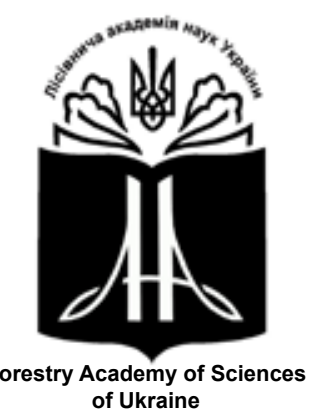

УДК 712.41:631

Наукові праці Лісівничої академії наук України Proceedings of the Forestry Academy of Sciences of Ukraine

http://fasu.nltu.edu.ua https://doi.org/10.15421/411805

Article received 2018.03.03

Article accepted 2018.05.31
ISSN 1991-606X print

ISSN 2616-5015 online

(a) $\triangle$ Correspondence author

Nadiia Oleksiichenko nadiaolex@ukr.net

Heroyiv Oborony st., 15, Kyiv, 03041, Ukraine

\title{
Вікові дерева парків-пам'яток садово-паркового мистецтва Тернопільщини
}

\author{
Н. О. Олексійченко ${ }^{1}$, С. М. Підховна²
}

Наведено дані щуодо сучасного стану збереження вікових дерев та їх кількісної структури в паркахпам'ятках садово-паркового мистецтва Тернопільщини. Вікові дерева на об 'єктах культурної спадщини представлені 30 видами та двома культиварами (Fagus sylvatica L.'Atropunicea' West. i Stypholobium japonicum Schott. 'Pendula'), більшість з яких (24 види) відносяться до відділу покритонасінних. Вікові особини деревних інтродуцеентів виявлено на території восьми парків (Більче-Золотеццького, Заліщцицького, Раївського, СкалаПодільського, Плотицького, Коропецького, Гримайлівського парків та в залишках парку в с. Млиниська).

Впродовж інвентаризаџійних досліджень здійснено комплексне оиінювання n'яти вікових дерев, які мають статус ботанічних пам'яток природи (вікові дерева, щуо мають вагоме культурне, історичне значення та повний заповідний режим) і ростуть у Раӥвському $і$ Залішицькому парках, охарактеризовано санітарний стан та визначено їхні таксаційно-біометричні показники. На зазначених об 'єктах виявлено вікові дерева-інтродуценти Gymnocladus dioicus (L.) C. Косh віком 130 років та Sophora јаропіса L. віком 150 років, які можуть бути рекомендовані до заповідання як ботанічні пам'ятки природи місиевого значення.

За результатами оцінки санітарного та естетичного стану визначних дерев запропоновано низку організаційних і технологічних заходів щзодо їх лікування, збереження та раціонального використання (створення карти геопросторового розташування вікових дерев, здійснення організаційних заходів з метою зменшення рекреаційного навантаження в межах площчі проекції крони, встановлення інформаційних іменних табличок, проведення лікувальних заходів щуодо уражених хворобами вікових дерев за сучасними екологічно обтрунтованими технологіями, у т. ч. і методами арбористики).

Ключові слова: інтродуценти; інвентаризаџія; ботанічна пам'ятка природи; заповідання; санітарний та естетичний стан.

Вступ. Парки-пам'ятки садово-паркового мистецтва відіграють у сучасному житті роль живих свідків багатовікових традицій. Суспільство все відчутніше усвідомлює загальнолюдську цінність пам'яток, розглядає їх як спільні надбання, визнає відповідальність перед наступними поколіннями за їх збереженість і вважає себе зобов'язаним переда- ти цю спадщину в усьому багатстві іiі автентичності. Важливим завданням, яке постає перед паркамипам'ятками садово-паркового мистецтва $є$ збереження на їх територіях природних і штучних паркових ландшафтів, пам’яток культурної спадщини, цінних інтродуцентів і вікових дерев. Виявлення останніх, визначення їхнього санітарного стану $€$

\footnotetext{
Олексійченко Надія Олександрівна - дійсний член Лісівничої академії наук України, доктор сільськогосподарських наук, професор кафедри ландшафтної архітектури та садово-паркового будівництва. Національний університет біоресурсів і природокористування України, вул. генерала Родімцева, 19, м. Київ, 03041, Україна. Тел.: 044-227-82-96, +38-098-330-22-78. E-mail: nadiaolex@ukr.net

2 Підховна Світлана Михайлівна - аспірант кафедри ландшафтної архітектури та садово-паркового будівництва. Національний університет біоресурсів і природокористування України, вул. генерала Родімцева, 19, м. Київ, 03041, Україна. Тел.: 044-227-82-96, +38-097646-72-89. E-mail: pidkhovna_s@ukr.net
} 
важливим критерієм під час комплексного оцінювання території для розробки проектів утримання та раціонального використання парків-пам'яток садово-паркового мистецтва.

Вперше пам'яткою природи старовікові дерева назвав професор Берлінського університету Олександр фон Гумбольт під час наукової експедиції у Північну Америку (1799-1804) (Galkin, Dragan \& Doiko, 2013).

Країни $з$ давніми і сильними природоохоронними традиціями - Німеччина, Англія, Польща, балтійські та скандинавські держави, давно і успішно займаються інвентаризацією і охороною вікових та інших видатних дерев (Boreiko, 2001). У Великій Британії та Німеччині (Пруссії) дослідження в такому напрямі розпочато ще 3 XVII ст. Причому в Пруссії інвентаризації та охороні підлягали висохлі велетні і навіть їхні пеньки, а в природоохоронних і ботанічних німецьких журналах містилися некрологи про загибель дерев. Нині особлива увага цій проблемі приділяється у Німеччині, де розроблено туристичний маршрут по місцях розташування старовікових дерев. Загалом традиція заповідання вікових дерев дуже поширена в Свропі: у Польщі заповідано 53 тис. дерев (2003 р.), в Італії станом на 2005 р. - 22 тис., у Великобританії - 22 тис. дерев (2008 р.) (Shnayder, Boreyko \& Stetsenko, 2011). У США віковим деревам присвячена книга «Славні та історичні дерева», в Литві та Естонії вікові дерева занесено в комп'ютерну базу даних (Galkin, Dragan\& Doiko, 2013).

Відповідно до Закону України "Про природнозаповідний фонд України", вікові та меморіальні дерева, які представляють історичну, біологічну, наукову, патріотичну, естетичну, символічну цінність, можуть бути захищені державою і мати статус ботанічних пам'яток природи (Law of Ukraine «On the Nature Reserve Fund of Ukraine», 1992).

В Україні, порівняно з іншими країнами Свропи, питання охорони, збереження та заповідання вікових дерев почали розглядати дещо пізніше. Першу роботу про вікові дерева на території України було опубліковано в 1883 р. О. Накропіним, стосовно дерев, які ростуть у Криму (Nakropin, 1883).

У 1910 р. польським ботаніком М. Рациборським вперше опубліковано підсумки інвентаризації вікових дерев у Західній Україні. У 1932 р. в Радянській Україні під охорону держави було взято 11 вікових дерев, а до 1935 р. у Західній Україні було взято під охорону 103 вікових і меморіальних дерева (Shnayder, Boreyko \& Stetsenko, 2011).

Найактивніше дослідження і роботи зі збереження та охорони вікових дерев розпочалися у другій половині XX ст. На цей час в Україні заповідними вважаються близько 2800 вікових і меморіальних дерев (в Тернопільській обл. - 295 дерев).

Упродовж останніх 20 років активізовано питання інвентаризації вікових дерев 3 метою їх охорони та заповідання в різних регіонах України (Boreiko, 2001, Dudyn, 2001, Cherniak, 2004, Kushnir, Gryrzerczyk, \& Suchanova, 2010, Shlapak et al., 2010-2011, Shnaider, Boreiko, \& Stetsenko, 2011, Oleksiichenko et al. 2012-2015). Зокрема, досліджено вікові дерева Львівської області (Dudyn, 2001); оцінено вікові дерева Волино-Поділля (Cherniak, 2004); здійснено дослідження вікових дерев в дендропарку «Софіївка» (Shlapak, Muzyka et al., 2010-2011). Низкою авторів (Shnaider, Boreiko, \& Stetsenko, 2011) зібрана наукова інформація про вікові дерева України в цілому; проінвентаризовано вікові дерева в межах Києва та Київської області (Kushnir, 2010); звернуто увагу на сучасний стан і збереження вікових дерев в регіоні Центрально-придніпровської височинної області (Oleksiichenko \& Gatalska (2012-2015); проведено наукові роботи щодо збереження вікових дерев в Національному дендропарку «Олександрія» (Galkin, Dragan, \& Doiko, 2013).

Охорона і збереження вікових та історичних дерев в Свропі $є$ проявом культури та поваги до національної спадщини. Починаючи з 2001 р., українські арбористи, за сприяння польських колег із Міжнародного товариства дослідження і охорони дерев, почали вивчати та запроваджувати на території України сучасні технології обрізування, лікування і оздоровлення вікових дерев (Kushnir, Gryrzerczyk, \& Suchanova, 2010).

Поряд з цим проблеми, пов'язані із виявленням та охороною вікових дерев в Україні, вирішуються повільно. Актуальними на сучасному етапі залишаються питання дослідження їх історичної складової у контексті етнокультурного ландшафту конкретної місцевості, визначення перспектив науководослідної та природоохоронної роботи зі збереження вікових дерев $з$ метою введення їх до переліку пам'яток природи та включення їх у туристичні маршрути різних регіонів нашої країни.

На Тернопільщині ще здавна значну увагу приділяли охороні вікових дерев. Так, ще у 1935 р. в Тернопільському воєводстві під охорону було взято 13 вікових дерев (Trysnyuk, 2014). Станом на 1.01.2018 p. у Тернопільській обл. охороняється 295 ботанічних пам'яток природи, 3 них 4 - загальнодержавного та 291 - місцевого значення. Серед ботанічних пам'яток природи місцевого значення виділено 109 вікових дерев та 33 екзотичні дерева (інтродуценти). Найбільша кількість вікових унікальних дерев знаходиться в парках-пам'ятках садово-паркового мистецтва, трапляються вони і на території наших дослідних об'єктів.

Об'єкти та методика досліджень. Об ' $\epsilon$ 'm дослідження - вікові дерева парків-пам'яток садовопаркового мистецтва Тернопільщини. Предмет дослідження - санітарний та естетичний стан вікових унікальних дерев парків-пам'яток садовопаркового мистецтва.

Мета досліджень полягає в оцінюванні санітарного та естетичного стану вікових унікальних дерев парків-пам'яток садово-паркового мистецтва та розробці природоохоронних рекомендацій щодо їх збереження.

Матеріалами для дослідження слугували літературні джерела, картографічні матеріали та результа- 
ти натурного обстеження деревних насаджень, яке здійснювали маршрутно-візуальним способом із застосуванням Інструкції 3 інвентаризації зелених насаджень у містах та селищах міського типу України (Instruction on the inventory of green plantations in settlements of Ukraine, 2001). Для характеристики стану деревної рослини визначали біометричні показники - діаметр стовбура на висоті 1,3 м та висоту дерева. Інформацію про місце розташування кожного дерева отримували за допомогою GPS Garmin Etrex 20 з прив'язкою до опорних точок на місцевості та наступним іiі коригуванням за матеріалами Д33 Landsat у ГІС ArcGis 9.2 (Bidolakh \& Kuzjovych, 2016). Вік дерев визначали за літературними даними (Shnaider et al., 2011, Cherniak et al., 2014). Розподіл деревних рослин за віковими категоріями здійснювали за 4-бальною шкалою (Shlapak et al., 2011). Категорію стану дерев визначали за «Санітарними правилами в лісах України» (Sanitary rules in forests of Ukraine, 2012): I - без ознак ослаблення, II - ослаблені, III - дуже ослаблені, IV - відмираючі, V - свіжий сухостій, VI - старий сухостій. Естетичний стан вікових дерев оцінювали за шестибальною шкалою, пристосованою для оцінки вікових дерев в історичних насадженнях (Shlapak et al., 2010).

Результати досліджень. Упродовж 2016-2017 pp. нами здійснено інвентаризаційні дослідження насаджень парків-пам'яток садово-паркового мис- тецтва Тернопільщини. За результатами опрацювання літературних джерел та натурних обстежень дослідних об'єктів виявлено 129 вікових дерев, які представлені 30 видами та двома культиварами (Fagus sylvatica L. 'Atropunicea' West. i Stypholobium japonicum Schott. 'Pendula'), 3 яких - 24 представники відділу покритонасінних. Аборигенні вікові дерева представлені 11 видами, що складає 37,5\% від їх загальної кількості. Вікові екземпляри деревних інтродуцентів виявлено на території восьми парків (Більче-Золотецькому, Заліщицькому, Раївському, Скала-Подільському, Плотицькому, Коропецькому, Гримайлівському парках та в залишках парку с. Млиниська). Коротку характеристику цінних вікових інтродуцентів парків-пам'яток садово-паркового мистецтва Тернопільської обл. наведено у табл. 1.

Отже, найбільша кількість вікових інтродуцентів (13 шт.) зосереджена у Більче-Золотецькому парку, які представлені шістьма видами. Окрім цих дерев, на увагу заслуговують вікові аборигени (чотири види) у кількості 18 екземплярів. Унікальним є екземпляр липи серцелистої, який вирізняється значними розмірами (780 см в обхваті стовбура), цікавою формою штамбу (чотиристовбуровість) і відмінним санітарним станом. Вікові дерева відіграють важливу роль у загальній композиції та ландшафтно-планувальній структурі БільчеЗолотецького парку.

Таблицяя 1

\section{Характеристика цінних вікових інтродуцентів парків-пам'яток садово-паркового мистецтва Тернопільщини}

\begin{tabular}{|c|c|c|c|c|c|}
\hline $\begin{array}{l}\text { № } \\
\text { 3.П. }\end{array}$ & Назва виду чи культивару & $\begin{array}{c}\text { К-сть, } \\
\text { шт. }\end{array}$ & $\begin{array}{c}\text { Діаметр, см/обхват } \\
\text { стовбура на висоті } \\
1,3 \text { м, см }\end{array}$ & $\begin{array}{l}\text { Приблизний } \\
\text { вік, років }\end{array}$ & $\begin{array}{c}\text { Значення та напрями } \\
\text { використання }\end{array}$ \\
\hline
\end{tabular}

\section{Gleditsia triacanthos L.}

2. Liriodendron tulipifera L.

3. Styphnolobium japonicum (L.) Schott

4. Juglans nigra L.

5. Acer pseudoplatanus L.

6. Pinus strobus L.

\section{Більче-Золотецький парк}

$\begin{array}{cccc}1 & 80 / 250 & 90 & \text { Маточна рослина } \\ 1 & 88 / 270 & 90 & \text { Культурно-просвітницьке, } \\ 1 & 60 / 180 & 90 & \text { маточні рослини } \\ 3 & 80-132 / 250-300 & 100-140 & \\ 3 & 84-130 / 260-320 & 100-160 & \text { Маточні рослини }\end{array}$

Загальна кількість вікових інтродуцентів - 13 шт.

\section{Заліщицький парк}

1. Ginkgo biloba L.

2. Gymnocladus dioicus (L.) K. Koch

3. Quercus borealis Michx.

4. Pinus pallasiana D.Don

5. Stypholobium japonicum Schott. 'Pendula'

6. Stypholobium japonicum Schott. 'Pendula'

7. Aesculus hippocastanum L.

$\begin{array}{lcc}1 & 120 / 350 & 185 \\ 1 & 98 / 300 & 130 \\ 1 & 105 / 320 & 170 \\ 1 & 79 / 240 & 150 \\ 1 & 110 / 310 & 150 \\ 1 & 64 / 170 & 150 \\ 1 & 110 / 330 & 160\end{array}$

Загальна кількість інтродуцентів - 7 шт.

\section{Раївський парк}

1. Pinus strobus L.

2. Larix decidua Mill.
$297,102 / 250,300$

$5 \quad 78-99 / 240-300$
200

$140-150$
Культурно-просвітницьке, маточні рослини

Маточні рослини

Культурно-просвітницьке, маточна рослина Маточна рослина

Загальна кількість вікових інтродуцентів - 7 шт. 
Продовження таблиичі 1

Скала-Подільський парк

1. Pinus nigra Arn.

2. Pinus strobus L.

3. Catalpa speciosa Ward.

4. Aesculus hippocastanum L.

5. Tilia heterophylla Vent.

6. Larix polonica Racib.
2

1

1

1

1
$97,103 / 300,320$

$84 / 260$

$56 / 170$

$114 / 350$

$229 / 720$

$113 / 350$
150

105

120

200

560

155

Загальна кількість вікових інтродуцентів - 7 шт.

\section{Плотицький парк}

1. Aesculus hippocastanum $\mathrm{L}$.

2. Acer pseudoplatanus L.

3. Robinia pseudoacacia L.

1. Platanus acerifolia Willd.

2. Ginkgo biloba L.

1. Acer pseudoplatanus L.

2. Tilia heterophylla Vent.

3. Aesculus hippocastanum L.

1. Pinus strobus L.

2

$$
\begin{gathered}
100,110 / 310,330 \\
100 / 310 \\
70,75 / 210,230
\end{gathered}
$$

Загальна кількість вікових інтродуцентів - 5 шт.

\section{Коропецький парк}

$\begin{array}{ccc}2 & 130,132 / 400,410 & 210-260 \\ 1 & 100 / 280 & 150\end{array}$

Загальна кількість вікових інтродуцентів - 3 шт.

\section{Гримайлівський парк}

$\begin{array}{lll}1 & 120 / 370 & 180 \\ 1 & 150 / 430 & 250 \\ 1 & 110 / 340 & 200\end{array}$

Загальна кількість вікових інтродуцентів - 3 шт.

Залишки парку в с. Млиниська

$$
280,90 / 244,290 \quad 100
$$

Маточна рослина

Загальна кількість вікових інтродуцентів - 2 шт.

Загальна кількість вікових інтродуиеетів - 47 шт.

Наступним за кількістю унікальних дерев є Раївський парк (с. Рай Бережанського р-ну) - паркпам'ятка садово-паркового мистецтва загальнодержавного значення, на території якого росте 23 вікових дерева (сім видів та один культивар Fagus sylvatica L.'Atropunicea' West.), сім 3 яких - інтродуценти. Парк закладений у 1760 р. (Cherniak et al., 2014). Гордістю парку є його старожил - 850-річний дуб Богдана Хмельницького (за легендою, український гетьман відпочивав поблизу нього під час походу на Львів у 1648 р. (Cherniak, 2004, Shnaider, Boreiko, \& Stetsenko, 2011). Дуб Богдана Хмельницького знаходиться на стадії відмирання, його крона зазнала обрізки у 2001 р. (під охороною - місце зростання дуба). Окрім дуба Богдана Хмельницького на території Раївського парку виявлено ще дві ботанічні пам'ятки природи - Дуб «Велетень» і Дуб «Богатир».

Серед вікових дерев у досліджуваних парках можна виокремити найстаріше дерево Tilia heterophylla Vent. (720 см в обхваті, орієнтовний вік560 років), який знаходиться в Скала-Подільському парку і потребує заходів щодо консервації. Загалом у Скала-Подільському парку знаходиться 13 віко- вих дерев, які представлені дев'ятьма видами та одним культиваром (Fagus sylvatica L. 'Atropunicea' West.), з них сім дерев $\epsilon$ інтродуцентами.

У Заліщицькому парку-пам'ятці садово-паркового мистецтва місцевого значення виявлено 12 вікових дерев, п'ять 3 яких $є$ аборигенними видами. Парк розташований у м. Заліщики, заснований наприкінці XIX ст. на лівому терасовому березі p. Дністер (Shnaider, Boreiko, \& Stetsenko, 2011, Cherniak et al., 2014). У парку знаходиться дві ботанічні пам'ятки природи - Дуб «Над Дністром» i Гінкго Ігнатія Браницького (рис. 1-2).

Вікові інтродуценти на інших дослідних об' єктах представлені в меншій кількості, проте вони відіграють важливу роль у ландшафтно-планувальній композиції парків.

Біометричні показники, розподіл за віковою категорією, оцінка санітарного та естетичного стану ботанічних пам'яток природи парків-пам'яток садово-паркового мистецтва Тернопільщини наведено у табл. 2 .

Потрібно звернути увагу на категорію стану Дуба Богдана Хмельницького (VI), який перебуває на стадії відмирання. Дещо у кращому стані знахо- 
диться Дуб «Велетень» (III категорія), а найкращим станом серед цих вікових дерев відзначаються Дуб «Богатир», Дуб «Над Дністром» і Гінкго Ігнатія Браницького (II категорія).

Ботанічні пам'ятки за віковими категоріями можна поділити на вікові (одне дерево - Гінкго Ігнатія Браницького) та багатовікові (чотири дерева); за категоріями стану - II (три дерева), III (одне дерево - Дуб «Велетень»), VI (одне дерево - Дуб Богдана Хмельницького).

На основі здійсненої оцінки санітарного стану ботанічних пам'яток природи пропонуємо низку організаційних, оздоровчих і технологічних заходів щодо їх збереження: а) створити карту геопрос-

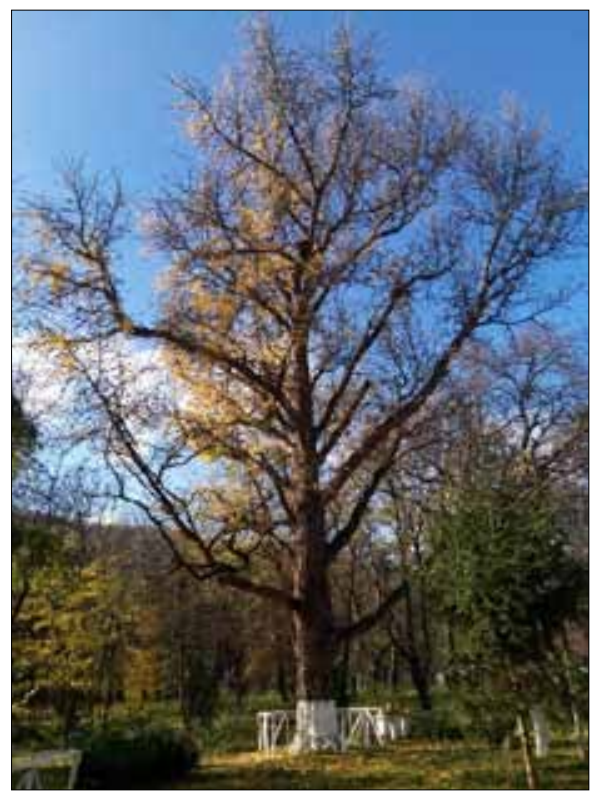

Рис. 1. Загальний вигляд

Гінкго Ігнатія Браницького (фото 2017 р.) торового розташування вікових дерев, пов'язану із комп'ютерною базою даних з фіксуванням усіх щорічних змін, які стосуються вікових дерев; б) здійснити організаційні заходи 3 метою зменшення рекреаційного навантаження в межах площі проекції крони (встановлення огорожі для повного обмеження доступу відпочиваючих до дерева (Дуб Богдана Хмельницького, Дуб «Велетень», Дуб «Богатир», Дуб «Над Дністром»); в) встановити інформаційні іменні таблички (Дуб «Велетень» та Дуб «Над Дністром»); провести лікувальні заходи щодо уражених хворобами вікових дерев за сучасними екологічно обгрунтованими технологіями, у т. ч. і методами арбористики.

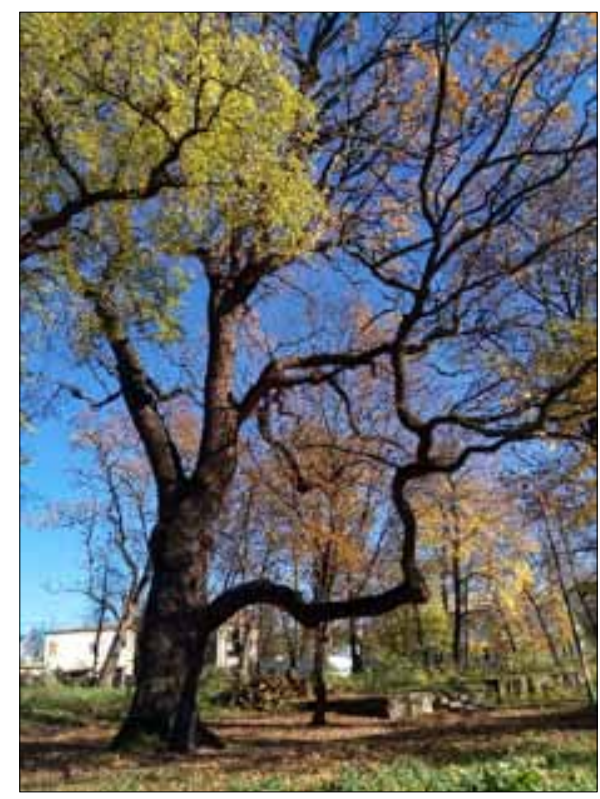

Рис. 2. Загальний вигляд

Дуба «Над Дністром» (фото 2017 р.)

Таблиия 2

Характеристика ботанічних пам'яток природи

\begin{tabular}{|c|c|c|c|c|c|c|c|c|}
\hline $\begin{array}{l}\text { № } \\
\text { 3.П. }\end{array}$ & $\begin{array}{l}\text { Назва ботанічної } \\
\text { пам’ятки природи }\end{array}$ & 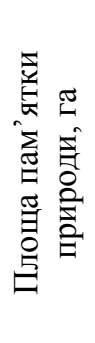 & 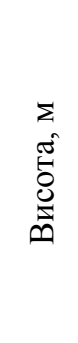 & 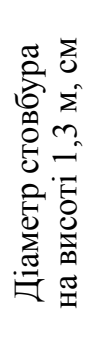 & 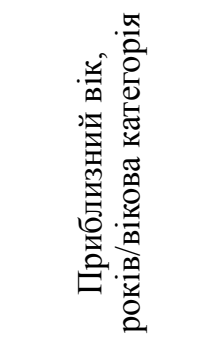 & 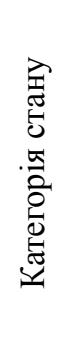 & 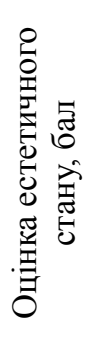 & 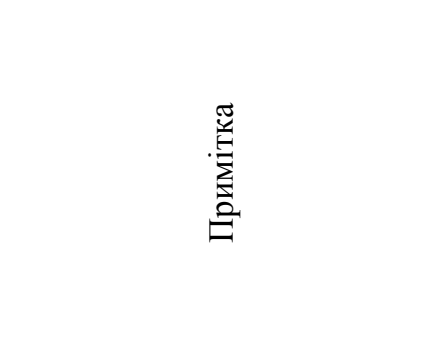 \\
\hline \multicolumn{9}{|c|}{ Раївський парк } \\
\hline 1 & Дуб Богдана Хмельницького & 0,04 & 13 & 244 & $850 /$ Б & VI & 6 & Збереження місця зростання \\
\hline 2 & Дуб «Велетень» & 0,02 & 23,5 & 200 & понад 500 / Б & III & 4 & $\begin{array}{c}\text { Стовбурова гниль, } \\
\text { пошкодження верхівки }\end{array}$ \\
\hline 3 & Дуб «Богатир» & 0,02 & 29 & 190 & понад 500 / Б & II & 4 & Стовбурова гниль \\
\hline \multicolumn{9}{|c|}{ Заліщицький парк } \\
\hline 4 & Дуб «Над Дністром» & 0,07 & 24 & 200 & $550 /$ Б & II & 3 & Стовбурова гниль \\
\hline 5 & Гінкго Ігнатія Браницького & 0,04 & 20 & 120 & 185 / B & II & 3 & - \\
\hline
\end{tabular}

Примітка. В - вікові; Б - багатовікові 
Під час проведення інвентаризаційних досліджень нами виявлено дерева-інтродуценти, які можуть бути рекомендовані до заповідання. Зокрема, дерево бундука канадського (Gymnocladus dioicus (L.) C. Koch) з приблизним віком 130 років (рис. 3) i софори японської (Stypholobium japonicum Schott. 'Pendula') з приблизним віком 150 років) (рис. 4), які ростуть у Заліщицькому парку. Коротку характеристику цих дерев наводимо у табл. 3 .

Бундук канадський (Gymnocladus dioicus (L.) C. Koch) росте у північно-західній частині Заліщицького парку, неподалік р. Дністер, софора япон- ська (Stypholobium japonicum Schott. 'Pendula') - у північній частині Заліщицького парку. Під час обстеження бундука канадського виявлено вегетативне природне поновлення (кореневі паростки 1-5-річного віку, які знаходяться в межах проекції крони), що може свідчити про успішну акліматизацію цього виду в дослідному регіоні. Природного поновлення софори японської не виявлено, проте, оскільки це дерево має змієподібну форму гілок і представляє цінність для садово-паркового будівництва, то його живці передано в лабораторію для проведення клонального мікророзмноження.

Таблиия 3

Характеристика дерев, рекомендованих до надання заповідного статусу

\begin{tabular}{|c|c|c|c|c|c|c|c|c|}
\hline $\begin{array}{c}\text { № } \\
\text { 3.П. }\end{array}$ & Назва виду чи культивару & 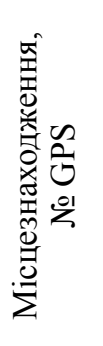 & 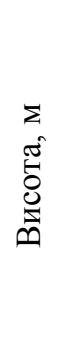 & 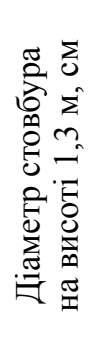 & 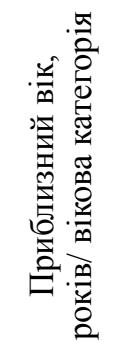 & 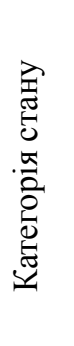 & 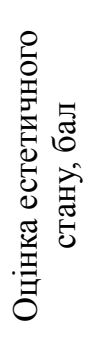 & 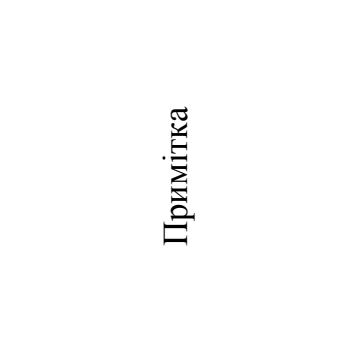 \\
\hline 1 & Gymnocladus dioicus (L.) C. Koch. & 283 & 27 & 98 & $130 / \mathrm{B}$ & I & 2 & Природне поновлення \\
\hline 2 & Styphnolobium japonicum L.'Pendula' & 85 & 8 & 64 & $150 / \mathrm{B}$ & II & 4 & Стовбурова гниль \\
\hline
\end{tabular}

Примітка. В - вікові; Б - багатовікові

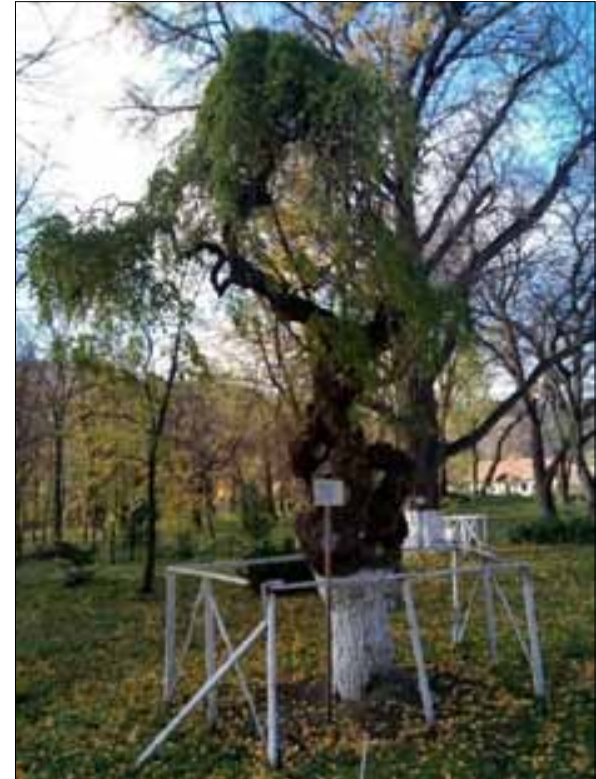

Рис. 3. Загальний вигляд вікового екземпляру Stypholobium japonicum Schott. 'Pendula' (фото 2017 р.)

Аналізуючи ретроспективний розвиток паркової території, можна стверджувати, що виявлені дерева $є$ одними 3 останніх унікальних дерев, які залишились від часів створення парку. Вони мають біологічну, наукову, історико-культурну i естетичну цінність, пов'язану зі значним віком та видовою рідкістю. Представлені дерева $€$

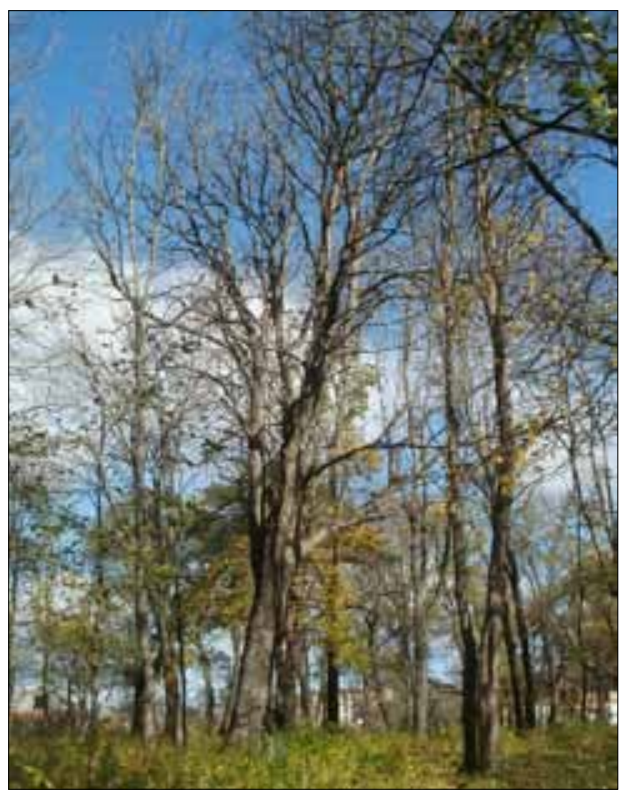

Рис. 4. Загальний вигляд вікового екземпляру Gymnocladus dioicus (L.) C. Koch

(фото 2017 р.)

деревами-старожилами, свідками минулого, рідкісними інтродуцентами, що добре адаптувалися в умовах Поділля, пам'ятками історії розвитку садово-паркового мистецтва. Зважаючи на це, вказані дерева доцільно взяти під охорону держави на правах ботанічних пам'яток природи місцевого значення. 
Вікові дерева, які ростуть на території парківпам'яток садово-паркового мистецтва Тернопільщини, $\epsilon$ його безцінним надбанням, історичною i культурною спадщиною, пам'ятками природи, тому доцільно вжити заходів 3 метою їх збереження та покращення санітарного стану.

Висновки. Вікові дерева в парках-пам'ятках садово-паркового мистецтва Тернопільщини представлені 30 видами та двома культиварами (Fagus sylvatica L. 'Atropunicea' West. i Stypholobium japonicum Schott. 'Pendula'), більшість з яких (24 види) відносяться до відділу покритонасінних. Biкові особини деревних інтродуцентів виявлено на території восьми парків (Більче-Золотецького, Заліщицького, Раївського, Скала-Подільського, Плотицького, Коропецького, Гримайлівського парків та в залишках парку в с. Млиниська).

Станом на 1.01.2018 р. у Тернопільській обл. охороняється 295 ботанічних пам'яток природи, 3 них чотири - загальнодержавного та 291 - місцевого значення. Серед ботанічних пам'яток природи місцевого значення виділено 109 вікових дерев та 33 екзотичні дерева (інтродуценти). Території п'яти ботанічних пам'яток природи місцевого значення входять до складу територій парків-пам'яток садовопаркового мистецтва - Раївського та Заліщицького.

Упродовж інвентаризаційних досліджень проведено комплексне оцінювання п'яти вікових дерев, які мають статус ботанічних пам'яток природи (вікові дерева, що мають вагоме культурне, історичне значення та повний заповідний режим) і ростуть у Раївському і Заліщицькому парках, охарактеризовано санітарний стан та визначено їхні таксаційнобіометричні показники.

Виявлено вікові дерева-інтродуценти Gymпосladus dioicus (L.) C. Koch віком 130 років та Stypholobium japonicum Schott. 'Pendula' віком 150 років, які за своєю біологічною, науковою, історикокультурною і естетичною цінністю можуть бути рекомендовані до заповідання.

За результатами оцінки санітарного та естетичного стану визначних дерев запропоновано низку організаційних і технологічних заходів щодо їх лікування та збереження (створення карти геопросторового розташування вікових дерев, здійснення організаційних заходів з метою зменшення рекреаційного навантаження в межах площі проекції крони, встановлення інформаційних іменних табличок, проведення лікувальних заходів щодо уражених хворобами вікових дерев за сучасними екологічно обгрунтованими технологіями, у т. ч. і методами арбористики).

\section{Бібліографічні посилання}

Bidolakh, D. I., \& Kuzjovych, V. S. (2016). Modern Methods of Greenery Inventory and Comprehensive Assessment of Landscape-Planning Structure of the Park-Sanatorium "Cherche". Scientific bulletin of the Ukrainian National Forestry University, 26.3, 42-48 (in Ukrainian).
Boreiko, V. E. (2001). Protection of ancient trees. Kyiv: Kyiv ecological and cultural center (in Russian).

Cherniak, V. M. (2004). Cultivated Volyno-Podillia Dendroflora, prospects for its use and enrichment. Ternopil: Ternopil national pedagogical university (in Ukrainian).

Cherniak, V. M., Synytsia, H. B., \& Piatkivskyi I. O. (2014). Unique pearls of nature of Ternopil region. Ternopil: Educational book - Bogdan (in Ukrainian).

Dudyn, R. B. (2001). The oldest trees of the old parks. Scientific bulletin of the Ukrainian National Forestry University, 11.4, 29-32 (in Ukrainian).

Galkin, S. I., Dragan, N. V., \& Doiko N. M. (2013). Experience of the conservation of ancient trees and historical compositions in arboretum Olexandria of the NAS of Ukraine. Plant introduction, 4, 42-50 (in Ukrainian).

Instruction on the inventory of green plantations in settlements of Ukraine (2001). Approved by the order of the Ministry of Construction, Architecture and Housing and Communal Services of 24.12.2001, №. 226 (in Ukrainian).

Kushnir, A. I., Gryrzerczyk, W., \& Suchanova, O.A. (2010). The newest technologies of maintainance of trees-veterans in Europe. Scientific bulletin of the Ukrainian National Forestry University, 21.16, 240245 (in Ukrainian).

Nakropin, O. (1883). Remarkable ancient large trees in the Crimea. Herald of gardening, fruit growing and gardening, 6, 272-275 (in Russian).

Oleksiichenko, N. O., \& Gatalska, N. V. (2013). Introduents of park-monuments of garden art of the Central highland area of Dnipro river. P. 2. Kyiv: Komprynt (in Ukrainian).

Oleksiichenko, N. O., Gatalska, N. V., \& Krachkovska, M. V. (2015). Retrospective analysis of the formation and development of the territory of the National University of Life and Environmental Sciences of Ukraine. Bila Tserkva: Pshonkovsky (in Ukrainian).

Oleksiichenko, N. O., Sovakova, M. O., Sovakov, O. V., Kitaiev, O. I., \& Sliusar, S. I. (2013). Species of the genus Tilia L. in plantations of the city of Kyiv. Kyiv: Komprynt (in Ukrainian).

On the Nature Reserve Fund of Ukraine: Law of Ukraine dated June 16, 1992 // Bulletin of the Verkhovna Rada of Ukraine (1992), № 34 (in Ukrainian).

Sanitary rules in forests of Ukraine: Order of the Ministry of Agrarian Policy and Food of Ukraine dated 21 March 2012, № 136 (in Ukrainian).

Shlapak, V. P., Muzyka, G. I., Vitenko, V. A., \& Marno, L. I. (2011). The biometric characterictics of fage-long woody plants in the Dendrological Park "Sofiyivka" end category distribution of them. Scientific bulletin of the Ukrainian National Forestry University, 21.5, 8-15 (in Ukrainian).

Shlapak, V. P., Myzuka, G. I., Vitenko, V. A., Marno, L. I., \& Gonchar, N. O. (2010). The evalvation metods of aesthetic conditions of the age-old plantations of trees in the national dendrological park "Sofiyivka" NAS of Ukraine. Scientific bulletin of the 
Ukrainian National Forestry University, 20.6, 8-13 (in Ukrainian).

Shnaider S. L., Boreiko V. E., \& Stetsenko N. F. (2011). 500 exceptional trees of Ukraine. Kiev: Kiev Ecological Cultural Center, State Service of the Reserve Ministry of Natural Resources of Ukraine (in Russian).

Trysnyuk, T. V. (2014). The history of the nature conservancy in the Ternopil region. Scientific bulletin of the Ukrainian National Forestry University, 24.1, 131-135 (in Ukrainian).

\section{Вековые деревья парков-памятников садово-паркового искусства Тернопольщины}

\author{
Н. А. Алексейченко ', С. М. Пидховна²
}

Парки-памятники садово-паркового искусства в современной жизни играют роль живых свидетелей многовековых традиций. Важной задачей парков-памятников садово-паркового искусства является сохранение на их территориях природных и искусственных парковых ландшафтов, памятников культурного наследия, ценных интродуцентов и вековых деревьев. Выявление последних, определение их санитарного и эстетического состояния является важным критерием при комплексной оценке территории для разработки проектов содержания и рационального использования парков-памятников садово-паркового искусства.

Объектом исследования были вековые деревья парков-памятников садово-паркового искусства Тернопольской области. Предмет исследования санитарное и эстетическое состояние возрастных уникальных деревьев парков-памятников садовопаркового искусства.

Цель исследований заключалась в оценке санитарного и эстетического состояния возрастных уникальных деревьев парков-памятников садовопаркового искусства Тернопольщины и разработка природоохранных рекомендаций по их сохранению.

Вековые деревья в парках-памятниках садовопаркового искусства Тернопольщины представлены 30 видами и двумя культиварами (Fagus sylvatica

\footnotetext{
Алексейченко Надежда Александровна - действительный член Лесной академии наук Украины, доктор сельскохозяйственных наук, профессор кафедры ландшафтной архитектуры и садовопаркового строительства. Национальный университет биоресурсов и природопользования Украины, ул. генерала Родимцева, 19, г. Киев, 03041, Украина. Тел.: 044-227-82-96, +38-098-330-22-78. E-mail: nadiaolex@ukr.net

Пидховна Светлана Михайловна - аспирант кафедры ландшафтной архитектуры и садово-паркового строительства. Национальный университет биоресурсов и природопользования Украины, ул. генерала Родимцева, 19, г. Киев, 03041, Украина. Тел.: 044-227-82-96, +38-097-646-72-89. E-mail: pidkhovna_s@ukr.net
}

L. 'Atropunicea' West. i Stypholobium japonicum Schott. 'Pendula'), большинство из которых (24 вида) относятся к отделу покрытосеменных. Возрастные особи древесных интродуцентов обнаружено на территории восьми парков (Бильче-Золотецкого, Залещицкого, Раевского, Скала-Подольского, Плотицкого, Коропецкого, Гримайловского и в остатках парка в с. Млыниска).

В течение инвентаризационных исследований проведено комплексное оценивание пяти вековых деревьев, которые имеют статус ботанических памятников природы (вековые деревья, имеющие важное культурное, историческое значение и полный заповедный режим) и растут в Раевском и Залищицком парках, охарактеризованы санитарное состояние, определены их таксационно-биометрические показатели.

На указанных объектах обнаружены вековые деревья-интродуценты - бундук канадский (Gymnocladus dioicus (L.) C. Koch) возрастом 130 лет и софора японская (Stypholobium japonicum Schott. 'Pendula') возрастом 150 лет. Анализируя ретроспективное развитие парковой территории, можно утверждать, что обнаруженные деревья являются одними из последних уникальных экземпляров, оставшихся со времен создания парка. Они имеют биологическую, научную, историкокультурную и эстетическую ценность, связанную со значительным возрастом и видовой редкостью. Учитывая это, указанные деревья целесообразно взять под охрану государства на правах ботанических памятников природы местного значения.

По результатам оценки санитарного и эстетического состояния выдающихся деревьев, предложен ряд организационных и технологических мероприятий по их лечению, сохранению и рациональному использованию (создание карт геопространственного расположения вековых деревьев, проведение организационных мероприятий с целью уменьшения рекреационной нагрузки в пределах площади проекции кроны, установление информационных именных табличек, проведения лечебных мероприятий пораженных болезнями вековых деревьев по современным экологически обоснованными технологиями, в т. ч. и методами арбористики).

Ключевые слова: интродуценты; инвентаризация; ботанический памятник природы; паркипамятники; заповедные объекты; санитарное и эстетическое состояние. 


\section{The old-age trees of the parks-monuments as park and garden art objects $a$ in Ternopil region}

\section{N. Oleksiichenko', S. Pidkhovna ${ }^{2}$}

Parks-monuments of garden art play in the modern life the role of living witnesses of centuries-old traditions. An important task facing parks, memorials of garden and park art objects, is the preservation of natural and artificial park landscapes, monuments of cultural heritage, valuable introduced and old-age trees on their territories. Detection of the latter, determining their vital and sanitary condition is an important criterion in the complex assessment of the territory for the development of projects for the maintenance and rational use of park-monuments of garden art.

The object of the research was the age-old trees of the monuments park-park art of Ternopil region. The subject of research - the vital and aesthetic state of the old-age unique trees in park-monuments of garden art.

The purpose of the research was to assess the vital and aesthetic state of the unique trees of the parkmonuments of landscape architecture of the Ternopil region and to develop the recommendations for their preservation.

The old-age trees in the park-monuments of landscape garden art of the Ternopil region are represented by 30 species and two cultivars (Fagus sylvatica L. 'Atropunicea' West. i Stypholobium

Nadiia Oleksiichenko - full Member of the Ukrainian Academy of Forest Sciences, Doctor of Agricultural Sciences, Professor of the Department of Landscape Architecture and Park-Gardening Construction of National University of Life and Environmental Sciences of Ukraine, Kyiv, 03041, Ukraine. Tel.: 044-227-82-96, +38098-330-22-78. E-mail: nadiaolex@ukr.net

Svitlana Pidkhovna - aspirant of the Department of Landscape Architecture and Park-Gardening Construction of National University of Life and Environmental Sciences of Ukraine, Kyiv, 03041, Ukraine. Tel.: 044-227-82-96, +38-097-646-72-89. E-mail: pidkhovna_s@ukr.net japonicum Schott. 'Pendula'), most of which (24 species) belong to the Department of Angiospermae. The old-age introducents were found on the territory of eight parks (Bilche-Zolotetskiy, Zalishchytskiy, Raivskiy, Skala-Podilskiy, Plotytskiy, Koropetskiy, Hrymailivskiy parks and in the remains of the park in Mlynysky village).

During inventory studies a comprehensive assessment of five old-age trees that have the status of botanical monuments of nature (old-age trees with significant cultural and historic significance and strict conservation regimes) has been carried out and are growing in the Rayivskiy and Zalishchytskiy parks, the sanitary condition has been characterized and their taxonomic and biometric indices.

On these objects, old-age trees-introdents (Gymnocladus dioicus (L.) C. Koch) - 130 years old and Stypholobium japonicum Schott. 'Pendula' - age 150 years old) have been identified. Analyzing the retrospective development of the park area, it can be argued that the trees discovered are among the last unique trees that have survived since the creation of the park and have a biological, scientific, historical, cultural and aesthetic value associated with a significant age and species rarity. It is expedient to take night natural monuments of local importance under the state protection .

According to the results of the assessment of the vital and aesthetic state of the prominent trees, a number of organizational and technological measures for their treatment, conservation and rational use have been proposed (creation of the map of the geospatial location of the trees, the organization of measures to reduce the recreational pressure within the area of the projection of the crown, the establishment of information nameplates, carrying out of sanitary measures on diseases affected by age trees on the basis of modern ecologically sound technologies, incl. and methods of arboretics).

Key words: introduents; inventory; botanical monument of nature; parks-monuments; protected objects; sanitary and aesthetic condition. 